\title{
INTERSTITIAL WATER STUDIES OF LATE QUATERNARY EASTERN MEDITERRANEAN SEDIMENTS WITH EMPHASIS ON EARLY DIAGENETIC REACTIONS AND EVAPORITIC SALT INFLUENCES
}

\author{
H.L. TEN HAVEN ${ }^{1}$, G.J. DE LANGE' ${ }^{1}$ and R.E. McDUFF ${ }^{2}$ \\ ${ }^{1}$ Department of Geochemistry, Institute of Earth Sciences, State University of Utrecht, Budapestlaan 4, 3584 CD Utrecht \\ (The Netherlands) \\ ${ }^{2}$ School of Oceanography WB-10, University of Washington, Seattle, WA 98195 (U.S.A.)
}

(Accepted for publication August 7, 1986)

\begin{abstract}
Ten Haven, H.L., De Lange, G.J. and McDuff, R.E., 1987. Interstitial water studies of Late Quaternary Eastern Mediterranean sediments with emphasis on early diagenetic reactions and evaporitic salt influences. In: J.E. van Hinte, M.B. Cita and C.H. van der Weijden (Editors), Extant and Ancient Anoxic Basin Conditions in the Eastern Mediterranean. Mar. Geol., 75: 119-136.

Interstitial waters of five piston cores from the Eastern Mediterranean were recovered by shipboard squeezing and analyzed for their major elements. Additionally, organic carbon, $\mathrm{CaCO}_{3}$ and $\mathrm{HCl}$ extractable $\mathrm{Mg}$ were determined in the sediments from these cores. Three cores contain sapropels, which are considered to be the sedimentary expression of anoxic periods during the Quaternary. The $\mathrm{pH}$ in the interstitial waters extracted from the sapropels is significantly lower than the $\mathrm{pH}$ of the interstitial waters from the surrounding sediment. It is suggested that the low pH in sapropel interstitial waters is induced by bacterial activity. Other dissolved elements are not influenced by these sapropel layers.

Core $\mathrm{T} 83-46$, taken in the hypersaline anoxic Tyro Basin, shows a strong downward $\mathrm{SO}_{4}$ decrease, accompanied by a strong $\mathrm{NH}_{4}$ increase. The interstitial water chemistry of the Tyro Basin sediment is attributed to selective leaching of evaporitic salt; first halite dissolution, later followed by gypsum dissolution. The interstitial water chemistry of core T83-45, taken in the adjacent Kretheus Basin, is dominated by diffusive processes, which became important after oxic conditions returned in this formerly anoxic hypersaline basin.
\end{abstract}

\section{Introduction}

The Quaternary stratigraphy of Eastern Mediterranean sediments is characterized by sapropels that are considered to be the sedimentary expressions of stagnation and devel. opment of anoxic conditions. These sediments are therefore interesting objects for interstitial water studies. Apart from the results of the DSDP program Leg 13 (Sayles et al., 1972;
Presley et al., 1972) and Leg 42A (McDuff et al., 1978; Bode and Sotelo, 1978), to our knowledge only one deep-sea piston core from the Western Mediterranean has been studied in detail for its interstitial water chemistry (Church et al., 1971; Michard et al., 1974). Milliman and Müller (1973) reported some preliminary interstitial water results from piston and gravity cores from the Eastern Mediterranean. Most of the interstitial water data obtained from DSDP 
drill sites in the Mediterranean show a significant increase in $\mathrm{Cl}$ with depth. The same feature is also found at many other locations overlying salt deposits (Gieskes, 1983, and references therein). In the Mediterranean this $\mathrm{Cl}$ increase is caused by underlying Messinian salt deposits.

Small anoxic basins are found in the Eastern Mediterranean, which find their origin in the dissolution of outcropping Messinian salt deposits (Ten Haven et al., 1985). Two similar anoxic hypersaline basins are known; viz. Tyro Basin (Jongsma et al., 1983) and Bannock Basin (Scientific Staff of cruise Bannock 1984 12, 1985). Preliminary interstitial water analyses of sediments from the Kretheus Basin, adjacent to the Tyro Basin, suggested that hypersaline and anoxic conditions existed in this basin up to very recently (De Lange and Ten Haven, 1983). Anoxic conditions, that also lasted until a few thousand years ago in basins of the Katia area, are reported by the Scientific staff of cruise Bannock 1984-12 (1985).

The present paper describes the interstitial water results obtained from five piston cores, including a core from the Tyro Basin and a core from the Kretheus Basin.

\section{Sampling procedures}

The cores were collected during a 1983 cruise with the R.V. Tyro to the Eastern Mediterranean. The cores were recovered with a piston corer and a gravity trip corer, serving as trigger weight, with attached Nansen bottles at 0.5 and $1.5 \mathrm{~m}$ above the sediment-water interface. The location of the cores is shown in Fig.1.

The shipboard working procedure is described in detail by De Lange (1984). Briefly the PVC lined core is cut into $1 \mathrm{~m}$ sections, sealed and stored horizontally at $3-4^{\circ} \mathrm{C}$. Interstitial water extraction is started within $24 \mathrm{~h}$. The core is lengthwise split with a hydraulic cutting device and one half is immediately transferred to a nitrogen filled glove bag in a walk-in refrigerator, which is kept at in-situ temperature (ca. $13^{\circ} \mathrm{C}$ ). After a subsample is taken for porosity determination, an interval of $5-15 \mathrm{~cm}$ of sediment is sampled for interstitial water extraction. The samples are then transferred via a sluice to a glove box flushed with high-purity nitrogen and squeezed with modified Reeburgh-type squeezers (Reeburgh, 1967) using pressures up to 15 bar. The oxygen concentration and temperature inside the glove box are monitored continuously. Oxygen was generally below $0.005 \%$. The interstitial water is collected in polyethylene bottles, which were acid cleaned, thoroughly rinsed with demineralized water and dried prior to their use. Subsequently the interstitial water is separated into four portions; one for shipboard analyses, one of $4 \mathrm{ml}$ for alkalinity determination, one of $8 \mathrm{ml}$, which is immediately acidified with $200 \mu \mathrm{l}$ of $4 N \mathrm{HCl}$ for onshore analyses, and the remainder, which is deep frozen. The bottom-water samples are divided into two portions; one in a polyethylene bottle, which is deep frozen after on board analyses, the other for oxygen analyses. The squeezed sediment is divided into two portions, one stored under nitrogen at $4^{\circ} \mathrm{C}$, the other stored at $-20^{\circ} \mathrm{C}$ for organic geochemical studies (cf. Ten Haven et al., this volume and 1987b).

\section{Experimental}

A total of $10-80 \mathrm{ml}$ of interstitial water was obtained per sample. On board, $\mathrm{NH}_{4}, \mathrm{NO}_{3}$ and $\mathrm{NO}_{2}$ were analyzed with a Skalar SA-400 autoanalyzer. Standards and blanks were prepared in a stock of nutrient-depleted Atlantic surface water. The $\mathrm{pH}$ of the interstitial water was measured with a $\mathrm{pH} / \mathrm{Eh}$ meter, Radiometer model 471 . Alkalinity was determined titrimetrically according to a method adapted from Strickland and Parsons (1968). Dissolved oxygen was determined by the Winkler method (Grasshoff et al., 1983).

The following constituents were analyzed within eight months after collection. If the amount of the retrieved water was too small for the subdivision mentioned above, the analyses were carried out on the portions previously used for alkalinity determination, correcting 


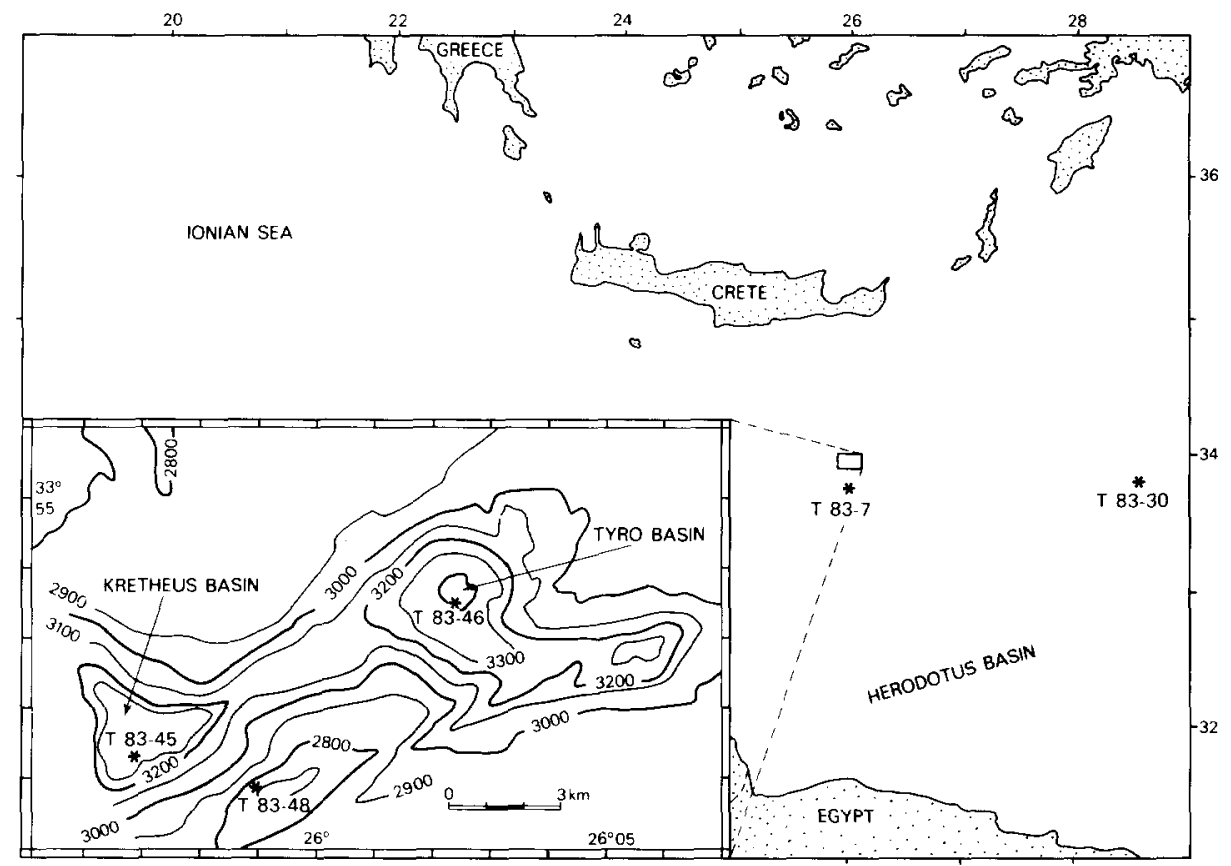

Fig.1. Location of the five piston cores. Core T83-7: $33^{\circ} 39.65^{\prime} \mathrm{N}, 25^{\circ} 59.00^{\prime} \mathrm{E}$ (water depth $2479 \mathrm{~m}$ ); core T83-30: $33^{\circ} 48.20^{\prime} \mathrm{N}$, $28^{\circ} 36.60^{\prime} \mathrm{E}$ (water depth $2812 \mathrm{~m}$ ); core $\mathrm{T} 83-45: 33^{\circ} 50.54^{\prime} \mathrm{N}, 25^{\circ} 56.73^{\prime} \mathrm{E}$ (water depth $3316 \mathrm{~m}$ ); core $\mathrm{T} 83-46: 33^{\circ} 52.02^{\prime} \mathrm{N}, 26^{\circ} 02.30^{\prime} \mathrm{E}$ (water depth $3473 \mathrm{~m}$ ); core $\mathrm{T} 83-48$ : $33^{\circ} 50.10^{\prime} \mathrm{N}, 25^{\circ} 59.05^{\prime} \mathrm{E}$ (water depth $2724 \mathrm{~m}$ ). The positions are based on Loran $\mathrm{C}$ navigation.

for the extra dilution. Results obtained during the last few years in our laboratory, have shown that these data are less accurate than those obtained by direct determination in the interstitial waters. $\mathrm{Na}, \mathrm{Mg}, \mathrm{K}$ and $\mathrm{Ca}$ were analyzed by routine flame Atomic Absorption Spectrometry with a Perkin Elmer 2380 model, using $\mathrm{Cs}$ and La as spectroscopic buffers. Sr was determined by electrothermal atomization AAS, using a Perkin Elmer 5000 atomic absorption spectrometer equipped with a HGA 400 graphite furnace model and Zeeman background correction. Standards were prepared in artificial seawater in order to minimize matrix effects. $\mathrm{Cl}$ was determined by Mohr titration with silver nitrate (Vogel, 1961). $\mathrm{SO}_{4}$ was determined by ion chromatography with conductivity detection using an Amolex 81 Ion-Chromatograph. The $\mathrm{SO}_{4}$ standards were made from Atlantic surface water.

Porosity of the sediment was calculated after wet and dry weighing of an aliquot of sediment, using the expression by Berner (1971):

porosity $=\frac{W \rho_{s}}{W \rho_{s}+(1-W) \rho_{w}}$

where $W=\% \mathrm{H}_{2} \mathrm{O}$ obtained by difference (wet wt./100), $\rho_{\mathrm{s}}=$ dry density of solid sediment material, assumed to be constant $\left(2.65 \mathrm{~g} \mathrm{~cm}^{-3}\right)$ and $\rho_{\mathrm{w}}=$ density of interstitial water $(1.03$ $\mathrm{g} \mathrm{cm}^{-3}$ ). No corrections were made for layers with an extremely high organic carbon content, which have usually a lower density (Müller and Suess, 1979) resulting in a lower porosity. To make the proper corrections for samples taken in core T83-46, the density of the interstitial water is assumed to be the same as the density of the brine $\left(1.199 \mathrm{~g} \mathrm{~cm}^{-3}\right.$; Ten Haven et al., 1985).

Detailed subsamples of the sediment cores were taken at irregular intervals, taking into account the visible changes in the sediment 
stratigraphy. In order to compare the "normal" Mediterranean sediment samples with sediment samples from the hypersaline Tyro Basin, all samples were desalted by dialysis against a continuous flow of demineralized water until the electroconductivity was below $100 \mu \mathrm{S}$. The desalted sediment suspension was then freezedried and homogenized. A weighed amount of dry sediment (ca. $0.5 \mathrm{~g}$ ) was reacted with $1 M$ $\mathrm{HCl}$ until the effervescence ceased. The $\mathrm{HCl}$ solution was decanted after centrifugation and the residue washed three times with distilled water. The combined supernatants $(\mathrm{HCl}$ plus distilled water portions) were collected. $\mathrm{Ca}$, $\mathrm{Mg}$ and $\mathrm{Sr}$ were determined in this $\mathrm{HCl} /$ water fraction with Inductively Coupled Plasma Emission Spectrometry (ARL type 34000). The sediment was oven-dried $\left(40^{\circ} \mathrm{C}\right)$ and organic carbon and nitrogen were determined by combustion with a Perkin Elmer 240 Elemental Analyzer. From the ICPES analyses the percentage $\mathrm{CaCO}_{3}$ was calculated and the organic carbon values were corrected for the $\mathrm{CaCO}_{3}$ content. The organic nitrogen was only accurate in samples with a high organic carbon content.

\section{Results}

The interstitial water data are shown in Figs.2A, 3A, 4A, 6A and 8A. The results obtained from the sediment analyses are shown in Figs.2B, 3B, 4B, 6B and 8B. A simplified lithological column, indicating the sapropels, is also presented in these figures. Detailed descriptions of the cores can be found in Ganssen and Troelstra, and Troelstra (both this volume).

The loss of sediment during coring with a piston corer is often difficult to estimate (e.g. McCoy, 1980), especially in an area such as the Mediterranean with highly varying sedimentation rates. Sometimes a gap even exists between the bottom of the trip core and the top of the piston core. In two cases, cores T83-7 and T83-45, a rough estimate of the sediment loss with the piston corer could be made from some of the observed interstitial water gradients $\left(\mathrm{NH}_{4}\right.$ profile for core $\mathrm{T} 83-7$; the $\mathrm{Na}$ and $\mathrm{Cl}$ profile for core T83-45). This approach could not be used for the other three cores, but a top layer of at least $40 \mathrm{~cm}$ can reasonably be assumed to be missing. The lines in the interstitial water figures were drawn after first, second or third order polynomial fitting calculations. Bottom water samples, indicated with an asterisk, generally show deviations for $\mathrm{Ca}, \mathrm{Sr}$ and $\mathrm{SO}_{4}$ probably caused by the storage procedure of these samples (deepfrozen). A likely explanation is that $\mathrm{CaSO}_{4}$ incorporating $\mathrm{Sr}$ precipitated during freezing and that this precipitate was not completely dissolved at the time of subsampling for the analyses. These data together with the data between brackets were excluded from the polynomial fitting calculations.

The gap in the profile of $\mathrm{Mg}, \mathrm{Ca}$ and $\mathrm{Sr}$ between the piston core and trip core of core T83-7 can best be explained by an underestimate of the sediment loss during coring, although an artifact induced by a difference in compression during coring between the trip core and piston core cannot be excluded. The gap is most pronounced in the $\mathrm{Mg}$ profile. Perhaps exchange processes occur between interstitial water and the tephra layer at the top of the piston core, providing a sink for magnesium (Gieskes, 1983), but additional information on the isotopic composition of dissolved strontium $\left({ }^{87} \mathrm{Sr} /{ }^{86} \mathrm{Sr}\right)$ and the oxygen isotopic composition of the interstitial water $\left({ }^{18} \mathrm{O} /{ }^{16} \mathrm{O}\right)$ is needed to verify this (e.g. Hawkesforth and Elderfield, 1978).

\section{Discussion}

The interstitial water data are divided into three groups for the purposes of discussion: (1) cores with a normal Mediterranean stratigraphy (T83-7, T83-30, T83-48); (2) the core from the anoxic brine-filled Tyro Basin (T83-46); and (3) the core from the Kretheus Basin (T83-45).

\section{Cores T83-7, T83-30 and T83-48}

Oxidation/reduction reactions, involving the oxidation of organic matter, dominate the 
diagenetic processes near the sediment-water interface. These chemical reactions are presented in Table 1, but instead of applying the Redfield gross molecule $\mathrm{C}_{106} \mathrm{H}_{263} \mathrm{O}_{110} \mathrm{~N}_{16} \mathrm{P}$ (Redfield, 1958; Froelich et al., 1979; Emerson et al., 1980) the reactions are given according to the $\mathrm{C}: \mathrm{N}$ ratio for organic matter as found in Mediterranean sapropels (the $\mathrm{N}$ analyses of non-sapropel samples were inaccurate, and therefore the $\mathrm{C} / \mathrm{N}$ ratios of the sapropels were arbitrary considered to be characteristic). The $\mathrm{C}: \mathrm{N}$ ratio of the sapropels encountered varies between 9 and 9.6, which is in fair agreement with the results of Sutherland et al. (1984). They reported a C:N ratio equal to about 10 for the organic matter in the $S_{1}$ sapropel. A similar approach was also proposed by Hartmann et al. (1973) (applying $\mathrm{C}_{106} \mathrm{H}_{239} \mathrm{O}_{110} \mathrm{~N}_{8} \mathrm{P}_{(0.2-0.7)}$ as the organic reactant in the oxidation reactions).

In sediments with high sedimentation rates redox processes, involving reactions a-d of Table 1, generally occur at very shallow burial depths (Froelich et al., 1979; Emerson et al., 1980). In order to monitor the subtle changes in $\mathrm{NO}_{3}$ and $\mathrm{NO}_{2}$ it is necessary to sample at very close intervals, starting from the sediment-water interface. Due to the large sampling intervals and the loss of the top of the sediment in the piston cores, we have clearly missed the zone of nitrification (reaction a) and of denitrification (reaction b). Therefore $\mathrm{NO}_{3}$ (all samples $<10 \mu \mathrm{mol} \mathrm{l}^{-1}$ ) and $\mathrm{NO}_{2}$ (all samples $\left.<1 \mu \mathrm{mol} \mathrm{l}^{-1}\right)$ results are omitted. The results of the $\mathrm{Fe}$ and $\mathrm{Mn}$ analyses will be discussed elsewhere.

The oxidation of organic matter in these cores is marked by an increase in $\mathrm{NH}_{4}$ with depth. The decrease in $\mathrm{SO}_{4}$ with depth in core T83-30 and T83-48 gives evidence for sulphate reduction (Figs.3A and $4 \mathrm{~A}$ ). Considering that this decrease in $\mathrm{SO}_{4}$ is not observed in core T83-7 (Fig.2A), and that the stratigraphy and the environmental conditions of the cores (e.g. water depth and oxygen content of the bottom water) are quite similar, either a difference in redox conditions exists or the decrease in $\mathrm{SO}_{4}$ is obfuscated by upward diffusion of $\mathrm{SO}_{4}$ (possibly due to the dissolution of underlying evaporitic deposits). The sulphate reduction and the concomitant oxidation of organic matter takes place under anaerobic conditions and is represented by reaction e of Table 1 . The increase in $\mathrm{NH}_{4}$ in core T83-7 (ca. $70 \mu \mathrm{mol}$ ) should theoretically correspond with a decrease of about $0.4 \mathrm{mmol} \mathrm{SO}$, which is however within the analytical error of the $\mathrm{SO}_{4}$ determination. The reduction of $5 \mathrm{mmol} \mathrm{SO}_{4}$ in

\section{TABLE 1}

Oxidation reactions of Mediterranean sedimentary organic matter

Oxidation reactions of organic matter

(a) Oxygen reduction:

$126 \mathrm{O}_{2}+\mathrm{C}_{106} \mathrm{H}_{245} \mathrm{O}_{110} \mathrm{~N}_{10} \mathrm{P}+12 \mathrm{HCO}_{3}^{-} \rightarrow 118 \mathrm{CO}_{2}+10 \mathrm{NO}_{3}^{-}+\mathrm{HPO}_{4}^{2-}+128 \mathrm{H}_{2} \mathrm{O}$

(b) Nitrate reduction:

$90.8 \mathrm{NO}_{3}^{-}+\mathrm{C}_{106} \mathrm{H}_{245} \mathrm{O}_{110} \mathrm{~N}_{10} \mathrm{P} \rightarrow 17.2 \mathrm{CO}_{2}+88.8 \mathrm{HCO}_{3}^{-}+50.4 \mathrm{~N}_{2}+77.6 \mathrm{H}_{2} \mathrm{O}+\mathrm{HPO}_{4}^{2-}$

(c) $\mathrm{Mn}^{4+}$ reduction:

$227 \mathrm{MnO}_{2}+\mathrm{C}_{106} \mathrm{H}_{245} \mathrm{O}_{110} \mathrm{~N}_{10} \mathrm{P}+346 \mathrm{CO}_{2}+104 \mathrm{H}_{2} \mathrm{O} \rightarrow 452 \mathrm{HCO}_{3}^{-}+5 \mathrm{~N}_{2}+227 \mathrm{Mn}^{2+}+\mathrm{HPO}_{4}^{2-}$

(d) $\mathrm{Fe}^{3+}$ reduction:

$212 \mathrm{Fe}_{2} \mathrm{O}_{3}+\mathrm{C}_{106} \mathrm{H}_{245} \mathrm{O}_{110} \mathrm{~N}_{10} \mathrm{P}+740 \mathrm{CO}_{2}+316 \mathrm{H}_{2} \mathrm{O} \rightarrow 846 \mathrm{HCO}_{3}^{-}+424 \mathrm{Fe}^{2+}+10 \mathrm{NH}_{3}+\mathrm{HPO}_{4}^{2-}$

(e) Sulphate reduction:

$53 \mathrm{SO}_{4}^{2-}+\mathrm{C}_{106} \mathrm{H}_{245} \mathrm{O}_{110} \mathrm{~N}_{10} \mathrm{P} \rightarrow 45 \mathrm{CO}_{2}+61 \mathrm{HCO}_{3}^{-}+10 \mathrm{NH}_{4}^{+}+53 \mathrm{HS}^{-}+45 \mathrm{H}_{2} \mathrm{O}+\mathrm{HPO}_{4}^{2-}$

$\mathrm{CaCO}_{3}$ dissolution/precipitation

(f) $\mathrm{CO}_{2}+\mathrm{H}_{2} \mathrm{O}+\mathrm{CaCO}_{3} \leftrightarrow 2 \mathrm{HCO}_{3}^{-}+\mathrm{Ca}^{2+}$

The stoichiometric reactions are listed in order of their occurrence, based on thermodynamical grounds modified from Emerson et al. (1980). The C:N ratio (106:10) is chosen according to the results of the C:N ratio of Mediterranean sapropels of this study and the C:N results of Sutherland et al. (1984). 

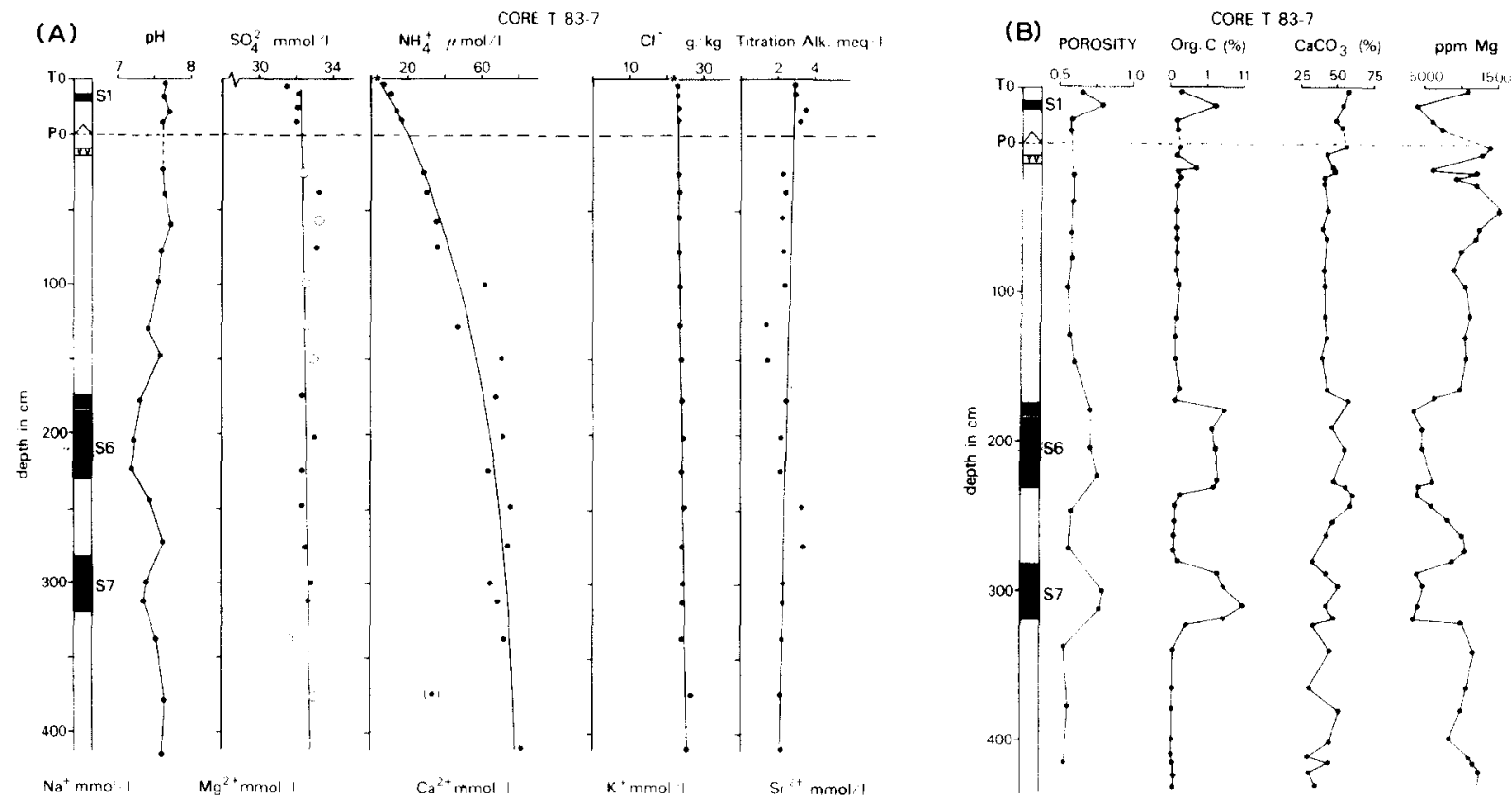

CORE T 83-7

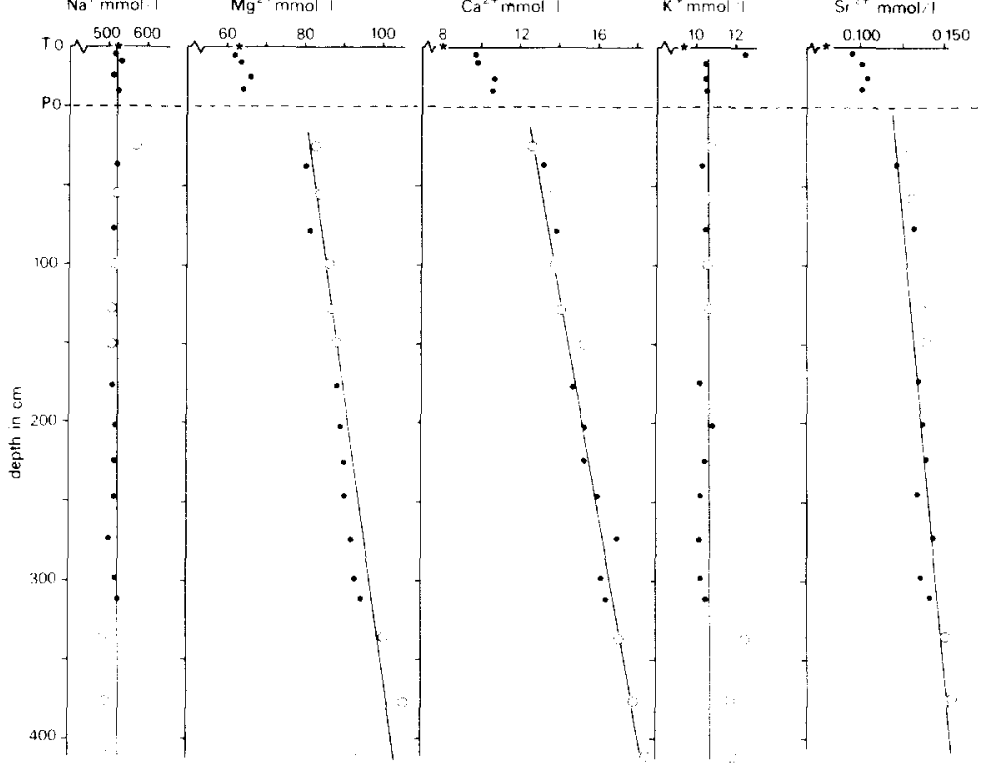

Fig.2.(A) Plot of interstitial water data versus depth in piston and trip core T83-7. The TO and PO marks indicate the top level of the trip core and the piston core, respectively. Sapropels are marked in black. Data represented by open symbols have been determined in sample portions used for determination of alkalinity, because small amounts of interstitial water were recovered at these sample points. Oxygen concentration of the bottom water is $6.11 \mathrm{mg} \mathrm{l}^{-1}$. The measured sulphate concentration of the bottom water is $24 \mathrm{mmoll}^{-1}$. Note that the $\mathrm{Cl}$ values are reported in $\mathrm{g} \mathrm{kg}^{-1}$. The values are, as a consequence of the applied analyses, dependent on the density, which increases with depth in core T83-45 (Fig.8).

(B) Porosity, organic carbon, $\mathrm{CaCO}_{3}$ and $\mathrm{HCl}$ extractable $\mathrm{Mg}$ in piston and trip core T83-7. To save space the organic carbon scale has been reduced. Maximum org. C. value is $11.0 \%$. The TO and PO marks indicate the top level of the trip core and of the piston core, respectively. Sapropels are marked in black. 

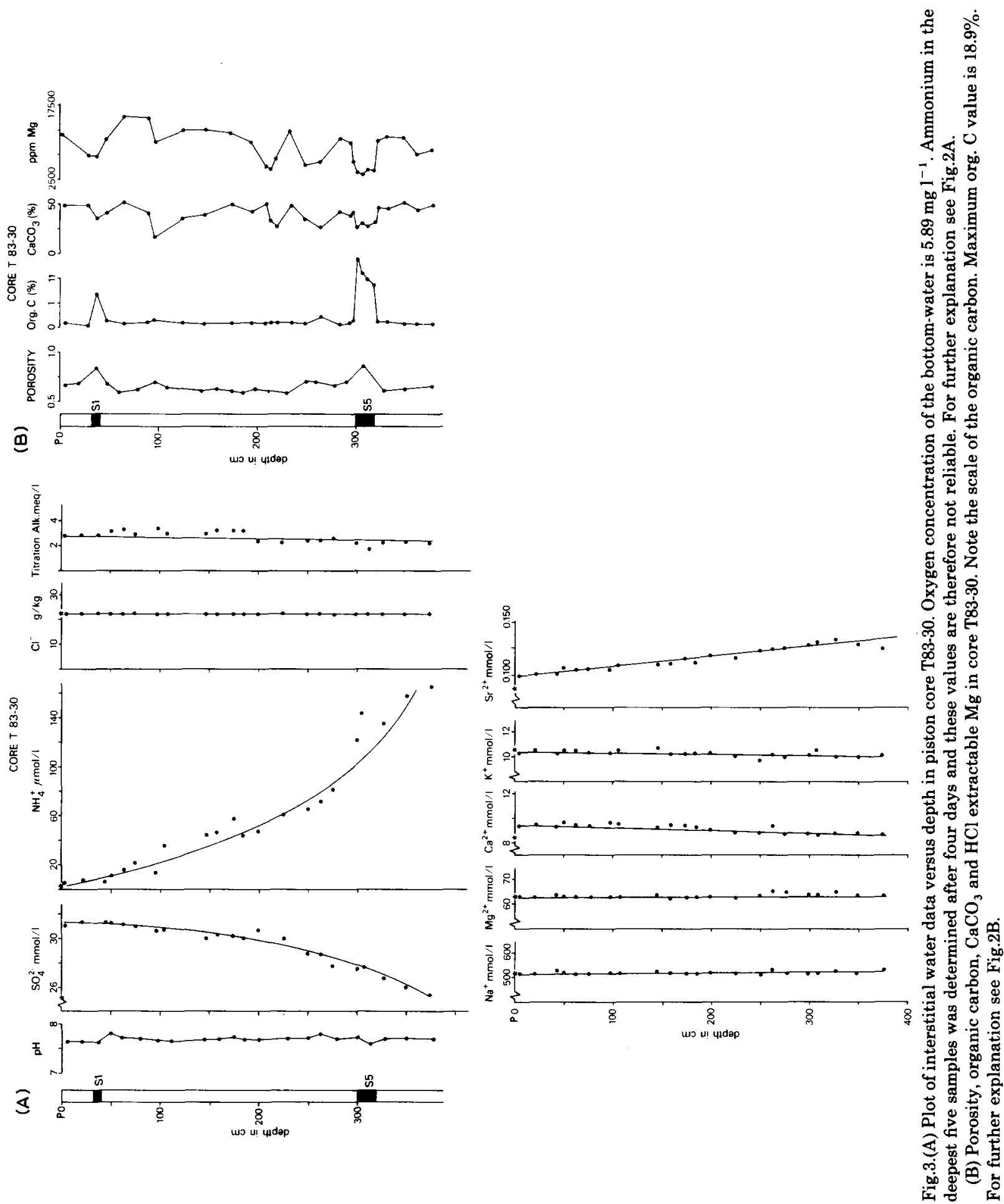

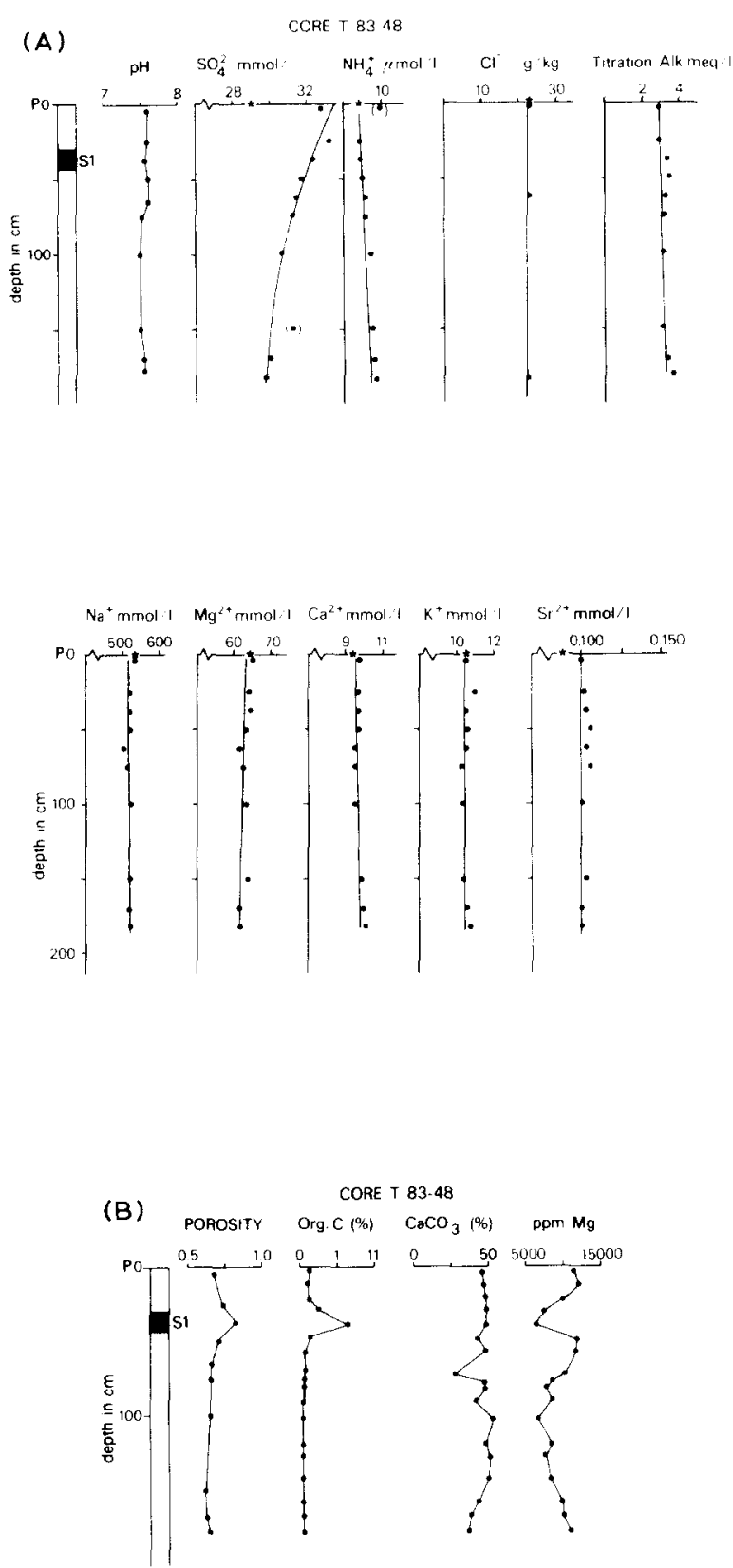

Fig.4.(A) Plot of interstitial water data versus depth in piston core T83-48. Oxygen concentration of the bottom water is $6.14 \mathrm{mg} \mathrm{l}^{-1}$. See Fig.2A for further explanation.

(B) Porosity, organic carbon, $\mathrm{CaCO}_{3}$ and $\mathrm{HCl}$ extractable $\mathrm{Mg}$ in piston core $\mathrm{T} 83-48$. Note the scale of the organic carbon. Maximum org. C value is $4.3 \%$. See Fig. $2 \mathrm{~B}$ for further explanation. core $\mathrm{T} 83-30$ and $3 \mathrm{mmol} \mathrm{SO}$ in core $\mathrm{T} 83-48$ should generate ca. 950 and $550 \mu \mathrm{mol} \mathrm{NH}_{4}$, respectively. However, the increase in $\mathrm{NH}_{4}$ in core T83-30 amounts only to ca. $160 \mu \mathrm{mol}$ and is negligible in core T83-48. The deficit of $\mathrm{NH}_{4}$ could be partly explained by exchange reactions with clay minerals, whereby up to half of the ammonium produced in diagenetic reactions can be fixed onto the ion-exchange sites (Rosenfeld, 1981), however we do not consider this to be a completely satisfactory explanation for the deficit of ammonium. A slight decrease in alkalinity is observed in core T83-7 (Fig.2A) which is difficult to explain. Both $\mathrm{SO}_{4}$ reduction and other oxidation reactions are accompanied by an increase in alkalinity. However, in a system open to molecular diffusion and assuming a constant calcite saturation, reactions $c$ and $d$ coupled with reaction $f$ can cause a decrease in alkalinity, accompanied with a decrease in Ca (Emerson et al., 1980, 1982). The alkalinity in cores $\mathrm{T} 83-30$ and $\mathrm{T} 83-48$ remains nearly constant with depth. It is frequently difficult to rationalize alkalinity profiles in carbonate-bearing sediments (e.g. Emerson et al., 1980). A decrease in alkalinity may result from the reduction in pressure caused by bringing the sediment to sea-level pressure (Murray et al., 1980), but quantitative prediction of this pressure effect is difficult to establish (Emerson et al., 1982). Loss of alkalinity and $\mathrm{Ca}$ due to $\mathrm{CaCO}_{3}$ precipitation after squeezing is reported by Gieskes (1973). This phenomenon is observed in sediments in which $\mathrm{SO}_{4}$ is strongly reduced and alkalinity exceeds over $20 \mathrm{meq} \mathrm{kg} \mathrm{g}^{-1}$. This is not the case in these cores, however. The percentage of calcium carbonate in the sediment (Figs.2B, 3B and 4B) varies between 16 and $59 \%$, indicating that the interstitial water is saturated with respect to calcium carbonate. Precipitation of calcium carbonate would lower the alkalinity and the concentration of $\mathrm{Ca}$. This could partly be the controlling mechanism in core T83-30 where $\mathrm{Ca}$ decreases with depth. Other precipitation reactions, such as the formation of siderite and rhodochrosite, can also control the carbonate system (Gieskes, 1983). 
The discrepancies in the predictions of the increase of alkalinity with depth might be traced back to the stoichiometric reactions of Table 1, where it is assumed that the organic matter is completely mineralized. In finegrained sediment under deep oceanic conditions organic matter is only partly and selectively decomposed. However, the reduction of $\mathrm{SO}_{4}$ will produce some anion (e.g. weak organic acids), which will certainly add alkalinity.

The increase in concentration of $\mathrm{Mg}, \mathrm{Ca}, \mathrm{Sr}$ and $\mathrm{Cl}$ as well as the constant concentrations of $\mathrm{K}$ and $\mathrm{Na}$ in core T83-7 correspond precisely with interstitial water data from the Western Mediterranean, that were published by Michard et al. (1974). Two mechanisms have been suggested to explain these features. Michard et al. (1974) proposed that underlying salt deposits are responsible for these profiles and suggested that either halite was missing or the mechanism is selective for alkaline earths. Milliman and Müller (1973) proposed that the breakdown of magnesian calcite, defined as calcite containing more than $4 \mathrm{~mol}_{\mathrm{o}} \mathrm{MgCO}_{3}$ in solid solution (Chave, 1952), is the principal source of the increase of the concentrations of $\mathrm{Mg}$ and $\mathrm{Ca}$ in interstitial waters of the Eastern Mediterranean. Magnesian calcite comprises $20-50 \%$ of the carbonate fraction in the deepsea sediments of the Eastern Mediterranean (Milliman and Müller, 1973). Unfortunately no alkalinity data were reported by Milliman and Müller (1973) nor by Michard et al. (1974), which could support the suggestion of magnesian calcite dissolution.

Messinian diapirs in the vicinity of coring site T83-7 are reported by several workers (Leité and Mascle, 1982; Le Pichon et al., 1979; Jongsma et al., 1983; Peters and Huson, 1985) and it seems reasonable to attribute the features in core T83-7 to salt influences. How then can the lack of $\mathrm{Na}$ enrichment with depth be explained?

One possibility is that a completely developed evaporitic sequence lies underneath, whereby the most soluble salts, the $\mathrm{K}$ and $\mathrm{Mg}$ salts, are present at the top. Development of such a sequence with a "bull's eye" zonation of saline minerals, according to the desiccated deep basin model of Hsü (1972), was found during Leg 42A of DSDP. The dissolution of the most soluble salts will cause a concentration increase of $\mathrm{K}, \mathrm{Mg}$ and $\mathrm{Cl}$ and this functions as a barrier for the dissolution of underlying halite. Such a model of selective dissolution of salt minerals can explain the profiles found in DSDP Site 374, where a lack of Na enrichment with depth was also observed (McDuff et al., 1978). Soluble salts were encountered at this DSDP site (Kuehn and Hsü, 1978). The $\mathrm{Mg} / \mathrm{Cl}$, $\mathrm{Ca} / \mathrm{Cl}$ and $\mathrm{Sr} / \mathrm{Cl}$ ratios of core $\mathrm{T} 83-7$ and $\mathrm{T} 83-30$ and the top sample of Site 374 (McDuff et al., 1978) are depicted in Figs.5B, C and D. Bearing in mind that in core T83-7 no increase in $\mathrm{K}$ is observed and that this core differs on that basis already from Site 374, these figures show that, compared with Site $374, \mathrm{Mg}$ and $\mathrm{Ca}$ are relatively more enriched than is $\mathrm{Cl}$. The increase in $\mathrm{Cl}$ with depth $\left(\Delta \mathrm{Cl}^{-}=100\right.$ mmol $\mathrm{l}^{-1}$ ) is counterbalanced by an increase in $\mathrm{Ca}, \mathrm{Mg}$ and $\mathrm{Sr}\left(\Delta \mathrm{Ca}^{2+}+\Delta \mathrm{Mg}^{2+}+\Delta \mathrm{Sr}^{2+}=50\right.$ $\left.\mathrm{mmol} \mathrm{l}^{-1}\right)$. Although differences in interstitial water chemistry exist between core T83-7 and Site 374 , we believe that the observed profiles in core T83-7 can best be explained by selective dissolution of Messinian salt deposits at depth and subsequent upward diffusion with additional exchange of alkaline earth ions $(\mathrm{Mg}, \mathrm{Ca})$ for alkaline ions $(\mathrm{K}, \mathrm{Na})$ similar to that observed at Site 374 . Note that the constancy of $\mathrm{K}$ and $\mathrm{Na}$ does not reflect quantitative exchange rather is simply the upper few meters of a diffusion dominated profile extending over several hundred meters.

The suggestion of Milliman and Müller (1973) that magnesian calcite is the principal source for $\mathrm{Mg}$ and $\mathrm{Ca}$ increase (possibly $\mathrm{Sr}$ ) is uncertain because of the following observations:

- In cores $\mathrm{T} 83-30$ and $\mathrm{T} 83-48$ the $\mathrm{HCl}$ extractable $\mathrm{Mg}$ of the sediment varies in the same range between 4000 and $15,000 \mathrm{ppm}$ as in core T83-7 (Figs.2B, 3B and 4B), but no increase in $\mathrm{Mg}$ with depth is observed in interstitial waters of cores T83-30 and T83-48. 

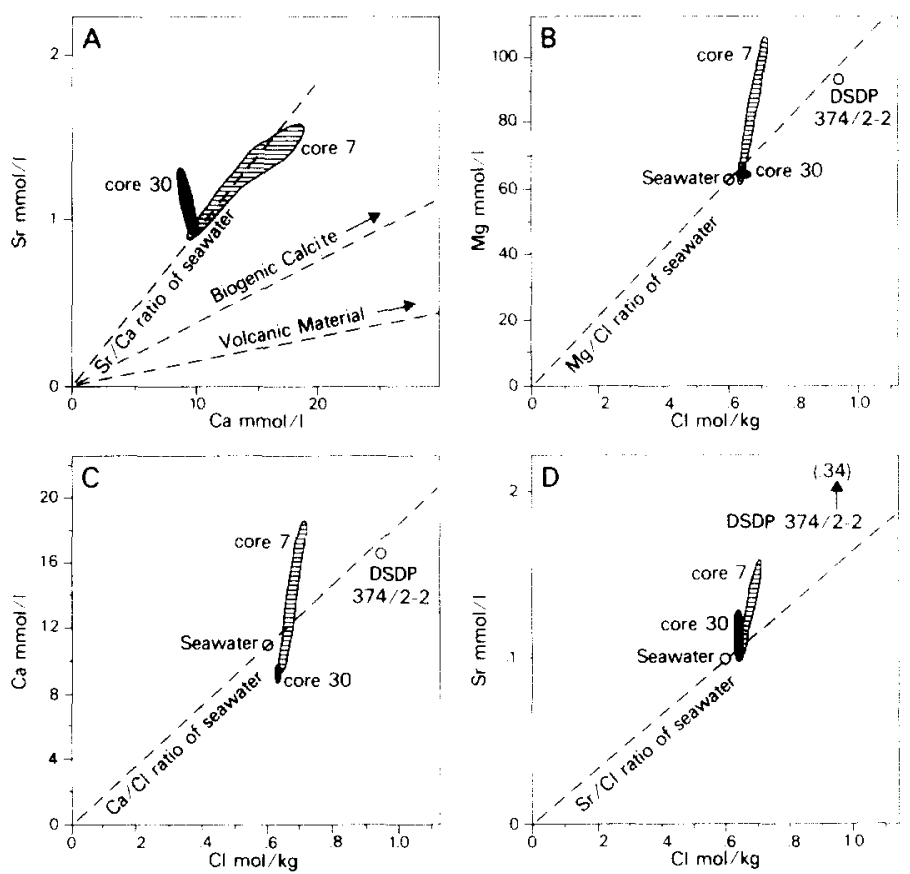

Fig.5. Cross plots of $\mathrm{Sr}$ versus $\mathrm{Ca}, \mathrm{Mg}$ versus $\mathrm{Cl}$, Ca versus $\mathrm{Cl}$ and $\mathrm{Sr}$ versus $\mathrm{Cl}$ for interstitial waters in piston core $\mathrm{T} 83-7$ and T83-30. DSDP 374/2-2 data after McDuff et al. (1978). (A) is drawn according to Hawkesforth and Elderfield (1978). Mediterranean seawater data are from Michard et al. (1974).

In this approach we assume that the trends in concentrations of acid-extractable $\mathrm{Mg}$ as observed in Figs.2B, $3 \mathrm{~B}$ and $4 \mathrm{~B}$ are due to differences in the magnesian calcite content. This is supported by the fact that the sapropel sequences are marked by a low content of magnesian calcite, which was reported by Milliman and Müller (1973). The results are presented in the figures as total acid-extractable $\mathrm{Mg}$ concentrations, but approximately the same trends are observed when the concentrations are normalized to total $\mathrm{CaCo}_{3}$ content.

- The alkalinity profile of core T83-7 gives no evidence for dissolution of magnesian calcite and there seems to be no decrease of magnesian calcite with depth as was observed in the cores investigated by Milliman and Müller (1973).

The increase in $\mathrm{Sr}$ concentration with depth in core T83-30 (Fig.3A) can be attributed to a preferential release during recrystallization of Sr-rich biogenic carbonate to form Sr-poor carbonate (Gieskes et al., 1975; Hawkesforth and Elderfield, 1978). The $\mathrm{Sr} / \mathrm{Ca}$ ratio of interstitial waters from core T83-7 falls on the seawater ratio line (Fig.5A), but carbonate recrystallization, which causes a deviating $\mathrm{Sr} / \mathrm{Ca}$ ratio (see core T83-30 in Fig.5A) can here be obscured by upward diffusion of Ca.

All three cores contain sapropel sequences, which are defined as "a discrete layer greater than $1 \mathrm{~cm}$ in thickness, set in open marine pelagic sediments and containing more than $2 \%$ organic carbon by weight" (Kidd et al., 1978). Although several hypotheses have been proposed to explain the occurrence and formation of these sapropels, it is generally accepted that they are formed in anoxic environments (see Ten Haven et al., this volume, for a review). Recently such conditions were discovered in the Tyro Basin (Jongsma et al., 1983) and in the Bannock Basin (Scientific staff of cruise Bannock 1984-12, 1985) in the Eastern Mediterra- 
nean. The $\mathrm{NH}_{4}$ concentration in interstitial waters from the Tyro Basin increases from 1000 up to $3000 \mu \mathrm{mol} \mathrm{l}^{-1}$ at $4 \mathrm{~m}$ depth (De Lange and Ten Haven, 1983; see also Fig.6A) and the pH of the interstitial waters is ca.7 (Fig.6A). Assuming that these concentrations are characteristic and thus representative for the anoxic periods, which led to sapropel formation during the Quaternary, it is interesting to observe that they are completely obliterated in the sapropel sequences of cores T83-7, T83-30 and T83-48. Approximately 7000-9000 years ago the last basin-wide anoxic event took place in the Eastern Mediterranean, leading to the formation of sapropel $S_{1}$. This period of time is sufficiently long to remove all $\mathrm{NH}_{4}$ by diffusion into the bottom water. Post-depositional oxidation of ammonium via nitrite to nitrate and subsequent diffusion of the latter species into the bottom water can also play an important role. The low $\mathrm{pH}$ of interstitial waters extracted from sapropels $S_{5}, S_{6}$ and $S_{7}$ (Figs.2A and $3 A$ ) cannot be a remnant of anoxic periods, because the diffusion coefficient of $\mathrm{H}$ is much higher than the diffusion coefficient of $\mathrm{NH}_{4}(\mathrm{Li}$ and Gregory, 1974). The vertical extent of the sapropels in conjunction with their organic carbon content seems to control the $\mathrm{pH}$. The most prominent sapropel, $\mathrm{S}_{6}$ in core T83-7, shows the largest decrease in $\mathrm{pH}$. Oxidation of pyrite $\left(\mathrm{FeS}_{2}+7 / 2 \mathrm{O}_{2}+\mathrm{H}_{2} \mathrm{O} \rightarrow \mathrm{Fe}^{2+}+2 \mathrm{SO}_{4}{ }^{2-}+2 \mathrm{H}^{+}\right)$ produces low pH conditions. The occurrence of gypsum in sapropels has been explained by precipitation of $\mathrm{Ca}$ released from dissolving biogenous carbonate, and $\mathrm{SO}_{4}$ released from pyrite oxidation (Calvert, 1983). The oxidation of pyrite can be caused by post-depositional diffusion of oxygen into the sediment, when aerobic conditions returned after the period of sapropel formation. This mechanism is consistent with the absence of gypsum below sapropels, becoming rare at their base and increasing towards their top (Cita et al., 1977). Such a sequence can be expected when oxygen diffuses downwards and starts to oxidize pyrite at the top of the sapropel. Because the older sapropels are presently buried at a depth where oxygen is already exhausted (a conclusion based on the $\mathrm{SO}_{4}$ profile in core $\mathrm{T} 83-30$ ), we suggest that the decrease in $\mathrm{pH}$, observed in interstitial water recovered from the sapropels, results from bacterial activity producing organic acids under anaerobic conditions. Bacterial organic geochemical marker molecules were indeed found in sapropel sequences (Ten Haven et al., this volume and 1987b). The sediments of lower porosity bounding the sapropels (Figs.2B, 3B and 4B) will limit the dispersal of $\mathrm{H}$ by diffusive processes. To test this hypothesis it is necessary to analyze the interstitial water for volatile fatty acids.

\section{Core T83-46}

This core, collected in the anoxic hypersaline Tyro Basin, is unique for the Mediterranean (Jongsma et al., 1983). The brine is thought to be derived from dissolution of outcropping Messinian salt (Ten Haven et al., 1985; Jongsma, this volume). The $\mathrm{Cl}$ and $\mathrm{Na}$ concentrations are extremely high and show no variation with depth (Fig.6A). No estimate can be made of the time of accumulation of the brine, as was successfully carried out by Addy and Behrens (1980) for the Orca brine on basis of a Cl profile. The $\mathrm{SO}_{4}$ decrease of $19 \mathrm{mmol} \mathrm{l}^{-1}$ is again not accompanied by an $\mathrm{NH}_{4}$ increase of 3.7 mmol $\mathrm{l}^{-1}$ as would be expected from the stochiometry of reaction (e) of Table 1. Small authigenic gypsum crystals were found in a box core from the Tyro Basin, but not in the piston core (Troelstra, this volume). The brine is presently undersaturated with respect to gypsum (Ten Haven et al., 1985) and a $\mathrm{SO}_{4}$ decrease due to gypsum precipitation is therefore excluded. The alkalinity seems to be controlled by precipitation of calcite and degradation of organic matter. In the upper $100 \mathrm{~cm}$ the calcite precipitation causes a decrease in the alkalinity, whereas in the lower part degradation of organic matter predominates causing an increase in alkalinity. There seems to be a relationship between $\mathrm{Ca}$ and $\mathrm{Sr}$ suggesting that calcite may also remove $\mathrm{Sr}$. However, incorporation of $\mathrm{Sr}$ in calcite is unlikely to be sufficient, as the $\mathbf{S r}$ content of calcite is low. An alternative explana- 


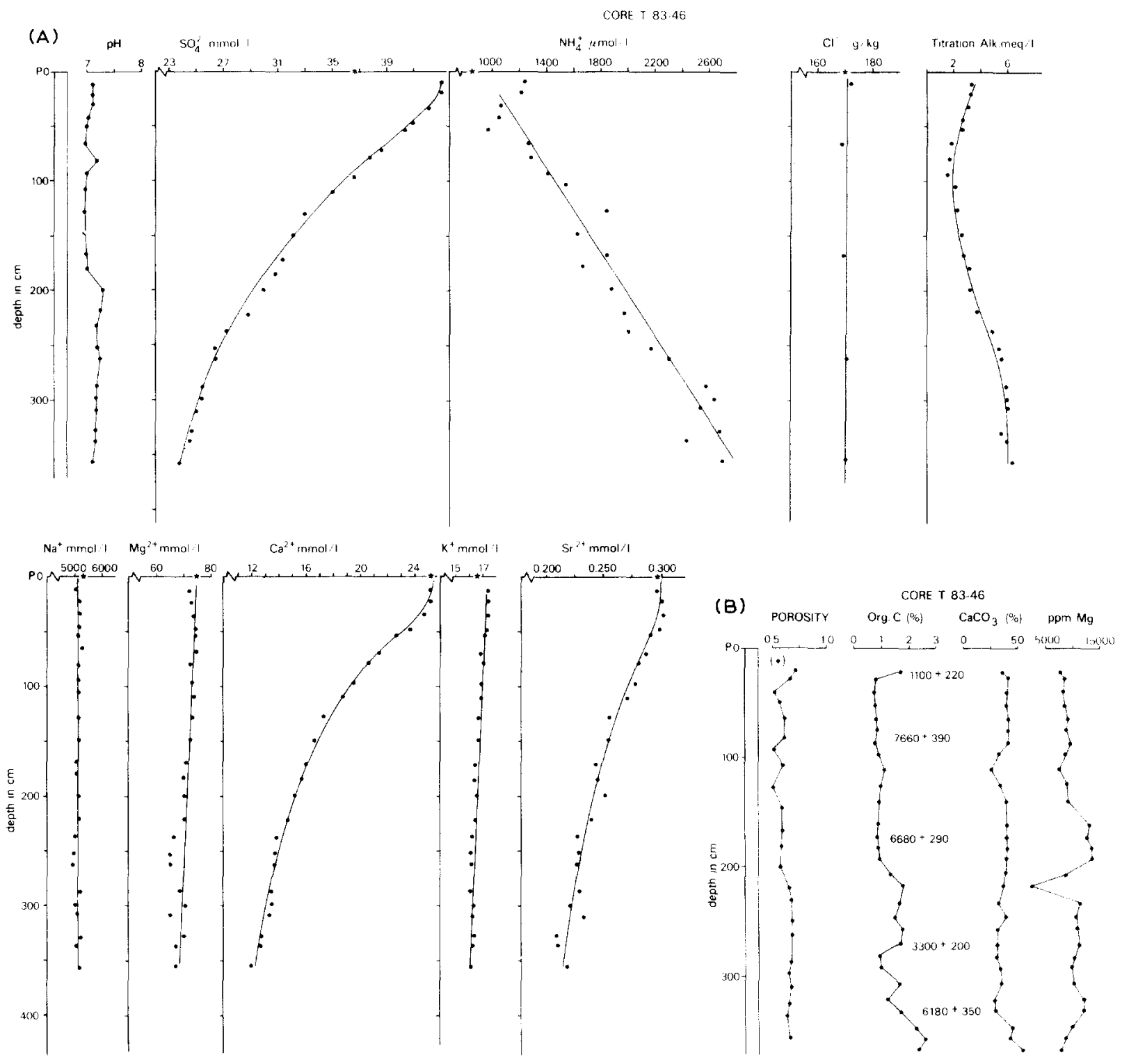

Fig.6.(A) Plot of interstitial water data versus depth in piston core T83-46. Oxygen concentration of the bottom water is 0 $\mathrm{mg} \mathrm{l}^{-1}$ (De Lange and Ten Haven, 1983). See Fig.2A for further explanation.

(B) Porosity, organic carbon, $\mathrm{CaCO}_{3}$ and $\mathrm{HCl}$ extractable $\mathrm{Mg}$ in piston core $\mathrm{T} 83-46$. The results of the ${ }^{14} \mathrm{C}$ dating of organic carbon are taken from Troelstra (this volume).

tion is that the Tyro brine is selectively formed, first by halite dissolution, later followed by gypsum dissolution (perhaps induced by continued tectonic activity), releasing $\mathrm{Ca}$ and $\mathrm{SO}_{4}$ as well as $\mathrm{Sr}$. The $\mathrm{Sr}$ profile is then only controlled by diffusion into sediment, whereas the $\mathrm{SO}_{4}$ and $\mathrm{Ca}$ profiles are also influenced by sulphate reduction and calcite precipitation respectively. A plot of Ca versus $\mathrm{Sr}$ (Fig.7) shows indeed a depletion of Ca when compared with the seawater ratio line.

Two mechanisms have been proposed to 
explain a decrease of $\mathrm{Mg}$ with depth in a reducing environment. Sholkovitz (1973) proposed that the cation-exchange capacity of clay minerals is increased with depth, because of removal of iron coatings, thereby making blocked sites available for Mg uptake. Drever (1971) suggested that $\mathrm{Mg}$ is removed by replacement of iron in a silicate phase. In trying to elucidate which of the two mechanisms prevails, Bischoff et al. (1975) showed on basis of laboratory experiments that both mechanisms could account for a decrease of $\mathbf{M g}$. A decrease of $\mathrm{K}$ with depth is also attributed to either cation-exchange processes (Russell, 1970) or to replacement in an insoluble, probably silicate phase (Zaitseva, 1962, in Mannheim, 1976). Sayles (1979) observed a relationship between the $\mathrm{K}$ depletion in interstitial water and the amount of continentally derived kaolinite in sediments from the Brasil basin.

McCoy and Stanley (1984) suggested that the sedimentation rate is probably extremely high in the Tyro Basin due to resedimentation processes triggered by active tectonism. These resedimentation processes became evident from the carbon dating analyses of organic carbon (Fig.6B; see also Troelstra, this volume). The porosity and organic carbon profiles are both influenced by these resedimentation processes (Troelstra, this volume). The carbonate content varies little with depth in contrast with $\mathrm{HCl}$ extractable $\mathrm{Mg}$ which shows a sharp negative peak at the "turnover" point from the partly pelagic to the totally resedimented sediment (Fig.6B). We have no explanation for this phenomenon, but it is remarkable that above this point $\mathrm{Mg}$ is slightly enriched.

\section{Core T83-45}

This core was collected in the presently oxic Kretheus Basin, separated by a sill at a depth of $3100 \mathrm{~m}$ with the anoxic, brine filled Tyro basin (Fig.1). The uppermost $3 \mathrm{~cm}$ of the piston core sediment is brown colored, whereas the rest of the sediment has a greyish-green color similar to the sediment color of core T83-46. This observation in combination with the $\mathrm{Cl}$ profile

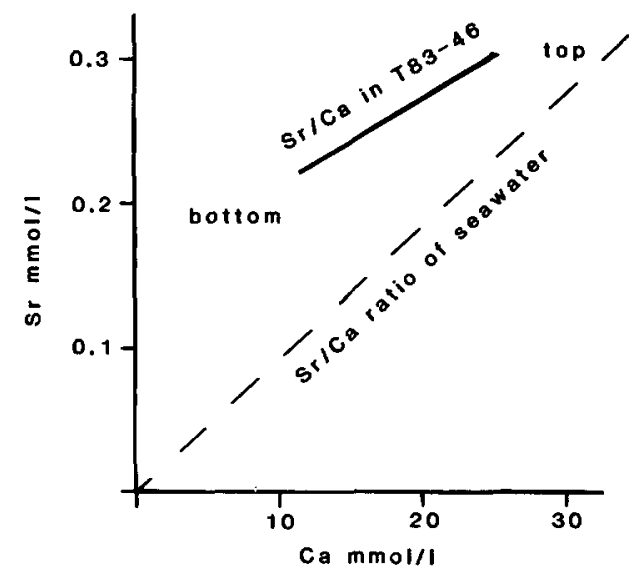

Fig.7. Relation of $\mathrm{Ca}$ versus $\mathrm{Sr}$ content of interstitial waters in core T83-46.

(Fig.8A) was interpreted as evidence for the presence of anoxic hypersaline conditions in the Kretheus Basin up until very recently (Jongsma et al., 1983; De Lange and Ten Haven, 1983). Preliminary diffusion calculations revealed the turnover time to be ca. 3000 years ago (De Lange and Ten Haven, 1983), suggesting a link with the Minoan eruption (see Troelstra, this volume).

As starting point for modelling and interpreting the observed profiles of core T83-45 (Fig.8A), we assume that the brine formerly present in the Kretheus Basin was essentially the same as the Tyro brine (Jongsma, this volume). At the time that normal Mediterranean seawater conditions returned diffusive processes became important. The $\mathrm{Cl}$ and $\mathrm{Na}$ profiles are excellent examples for diffusive controlled processes. Sjöberg et al. (1984) found similar profiles of $\mathrm{Cl}$ and $\mathrm{Na}$ in interstitial waters from post-glacial black clays, but the chlorinity range (0-7\%) in their study is different. The increase in $\mathrm{Cl}(1372$ mmol $1^{-1}$ ) is almost exactly counterbalanced by the increase of $\mathrm{Na}\left(1365 \mathrm{mmol} \mathrm{l}^{-1}\right)$, which is a logical consequence of the restriction of electro neutrality. (The $\mathrm{Cl}$ values in $\mathrm{g} \mathrm{kg}^{-1}$ were transformed to values in $\mathrm{mmol} \mathrm{l}^{-1}$ assuming a linear relationship between density and chlorinity of Mediterranean seawater, with $\mathrm{Cl}=22 \%$. $\rho_{\mathrm{w}}=1.03 \mathrm{~g} \mathrm{~cm}^{-3}$, and density and chlorinity of the Tyro brine, with $\mathrm{Cl}=170 \%$, 

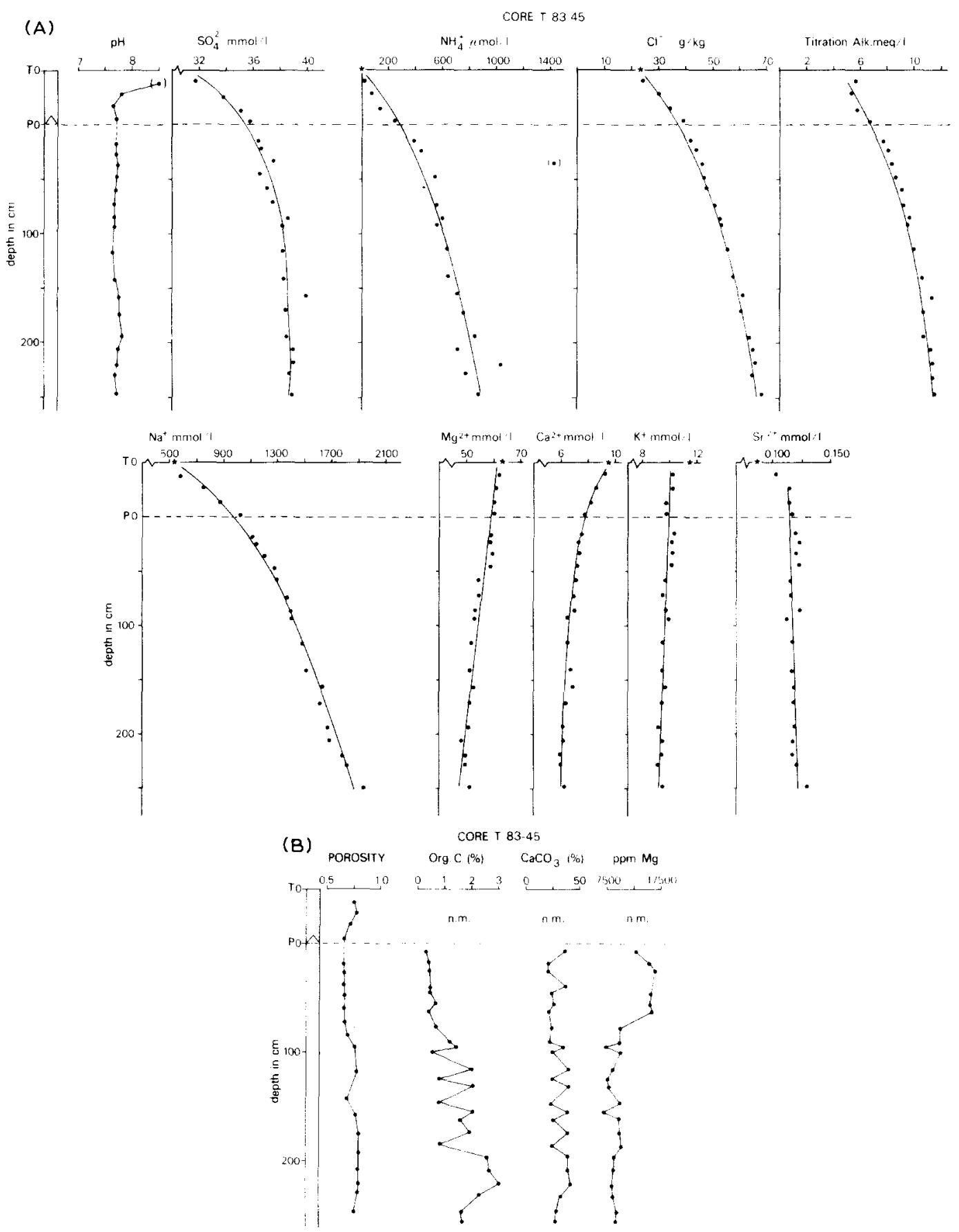

Fig.8.(A) Plot of interstitial water data versus depth in piston and trip core T83-45. Oxygen concentration of the bottom water is $6.03 \mathrm{mg} \mathrm{l}^{-1}$. The measured sulphate concentration of the bottom water is $24 \mathrm{mmol} \mathrm{l}^{-1}$. See Fig.2A for further explanation.

(B) Porosity, organic carbon, $\mathrm{CaCO}_{3}$ and $\mathrm{HCl}$ extractable $\mathrm{Mg}$ in piston and trip core T83-45. n.m. = not measured. See Fig. $2 \mathrm{~B}$ for further explanation. 
$\rho_{\mathrm{w}}=1.19 \mathrm{~g} \mathrm{~cm}^{-3}$.) It is noteworthy that the $\mathrm{Cl}$ content of the bottom water in the Kretheus Basin (23\%) is slightly higher than that of the bottom waters collected at other sites $(22 \%)$ ). A number of possible diffusion scenarios were constructed (see for theoretical background McDuff and Gieskes, 1976) and compared to the concentration gradient observed in the sediment. Cross-coupling terms, resulting from the electroneutrality requirement, were taken into account in the diffusion calculations (calculated according McDuff and Ellis, 1979). It is noteworthy to mention that there is especially an acceleration of $\mathrm{Sr}$ and $\mathrm{SO}_{4}$ compared to $\mathrm{Ca}$, due to their cross-coupling terms. Using the models which gave the best fit (e.g. Fig.9), the calculated range for the turnover time is estimated to be $250-4000$ years, depending on the boundary conditions (i.e., the depth at which the Kretheus chlorinity is equal to the
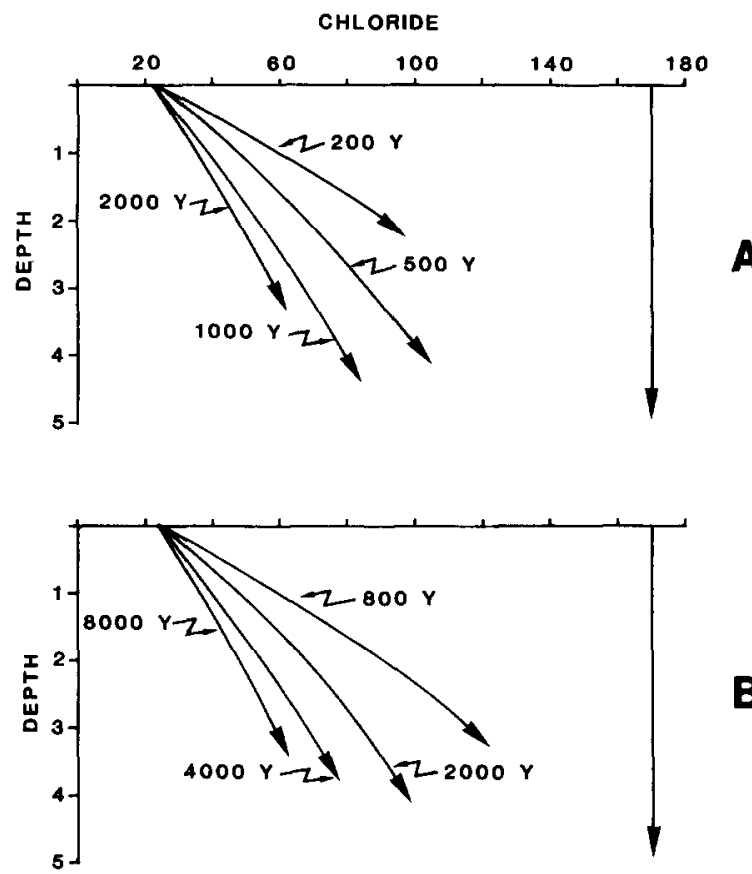

B

Fig.9. Model plots of chloride diffusion calculations with fixed depth at $50 \mathrm{~m}$ (A) and at $25 \mathrm{~m}$ (B). Boundary conditions: initial concentration $170 \%$ shifted to $21 \%$ at $T=0$. Calculated for diffusion coefficient $D=1.34 \times 10^{-5} \mathrm{~cm}^{2} \mathrm{~s}^{-1}$ and cross-coupling term 0.78 . Seetext for discussion.

A chlorinity of the Tyro Basin; see Fig.9A and B). The $\mathrm{NH}_{4}$ profile also reflects a diffusion controlled intermediate between values found in the normal Mediterranean cores and the Tyro core. The contribution of $\mathrm{NH}_{4}$ due to oxidation of organic matter since the cessation of anoxic bottom-water conditions, cannot be estimated. Like $\mathrm{Cl}$ and $\mathrm{Na}$ the $\mathrm{SO}_{4}$ profile can be explained by diffusion of sulphate in to the bottom water, taking as starting point, a profile found in the Tyro Basin (the only requirement was to have the proto-Kretheus not quite as sulphate reducing as the present Tyro). A test would be provided by a longer core, in order to show the relic effects of sulphate reduction at deeper levels in the Kretheus Basin. The origin of $\mathrm{Ca}, \mathrm{Sr}$ and $\mathrm{SO}_{4}$ enrichment is most likely from the dissolution of calcium sulphate phases. However, the high alkalinity values makes it difficult to interpret the $\mathrm{Ca}$ profile as calcite precipitation will dominate the transport terms. The $\mathrm{Sr}$ data follow the diffusion relaxation seen in other anions and cations. This is illustrated in Fig.10.

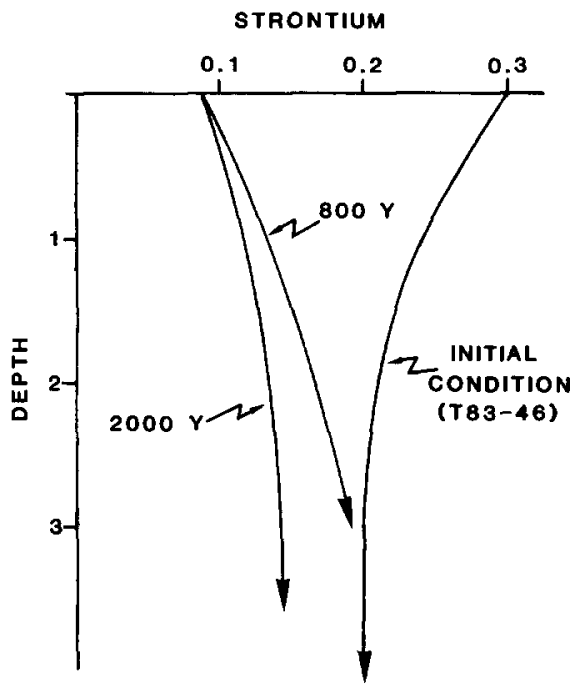

Fig.10. Model plot of strontium diffusion calculations. Boundary conditions: initial concentration $0.3 \mathrm{mmol} \mathrm{l}^{-1}$ shifted to $0.09 \mathrm{mmol}^{-1}$ at $T=0$. Calculated for diffusion coefficient $D=4.90 \times 10^{-6} \mathrm{~cm}^{2} \mathrm{~s}^{-1}$ and cross coupling term 3.55. Fixed depth at $25 \mathrm{~m}$. See text for discussion. 


\section{Acknowledgements}

Analytical support was given by T. Bouten, H. Dekker and J. Helmig. The ICPES analyses were carried out under supervision of $\mathrm{J}$. Kocken. The marine technicians of the Netherlands Institute of Sea Research (NIOZ) and the captain and his crew of the R.V. Tyro provided technical and logistical assistance. The autoanalyzer was put at our disposal by the Netherlands Geological Survey (RGD). The cruise was financed by the Netherlands Council of Sea Research (NRZ). The first author received a research grant (18.23.09) by the Netherlands foundation for Earth Science Research (AWON) with financial aid from the Netherlands Organization for the Advancement of Pure Research (ZWO). The expedition of the R.V. Tyro to the Eastern Mediterranean was a joint program of the Marine Geology group of the Free University of Amsterdam and the Marine Geochemistry group of the University of Utrecht. Comments made by B.J. Presley, C.H. van der Weijden and an anonymous reviewer are gratefully acknowledged.

\section{References}

Addy, S.K. and Behrens, E.W., 1980. Time of accumulation of hypersaline anoxic brine in Orca basin (Gulf of Mexico). Mar. Geol., 37: 241-252.

Berner, R.A., 1971. Principles of Chemical Sedimentology. McGraw-Hill, New York, N.Y., 240 pp.

Bischoff, J.L., Clancy, J.J. and Booth, J.S., 1975. Magnesium removal in reducing marine sediments by cation exchange. Geochim. Cosmochim. Acta, 39: 559-568.

Bode, G.W. and Sotelo, V.S., 1978. Interstitial water results leg 42A. In: K.J. Hsü, L. Montadert et al., Initial Reports of the Deep Sea Drilling Project, Vol. 42A. U.S. Govt. Printing Office, Washington, D.C., pp.1207-1209.

Calvert, S.E., 1983. Geochemistry of Pleistocene sapropels from the eastern Mediterranean. Oceanol. Acta, 6: 255-267.

Chave, K.E., 1952. A solid solution between calcite and dolomite. J. Geol., 60: 190-192.

Church, T.M., Bernat, M. and Michard, G., 1971. Distribution des élements alcalino-terreux dans les eaux inter stitielles d'une carotte de Méditerranée occidentale. C.R. Acad. Sci., Ser. D, 273: 2031-2033.

Cita, M.B., Vergnaud-Grazzini, C., Robert, C., Chamley, H., Cianranfi, N. and d'Onofrio, S., 1977. Paleoclimatic record of a long deep sea core from the eastern Mediterranean. Quat. Res., 8: 205-235.

De Lange, G.J., 1984. Shipboard pressure-filtration system for interstitial water extraction. Meded. Rijks Geol. Dienst, 38: 209-214.

De Lange, G.J. and Ten Haven, H.L., 1983. Recent sapropel formation in the eastern Mediterranean. Nature, 305: $797-798$.

Drever, J.I., 1971. Magnesium-iron replacement in clay minerals in anoxic marine sediments. Science, 172: $1334-1336$.

Emerson, S., Janhke, R., Bender, M., Froelich, P., Klinkhammer, G., Bowser, C. and Setloch, G., 1980. Early diagenesis in sediments from the eastern equatorial pacific. I. Pore water nutrient and carbonate results. Earth Planet. Sci. Lett., 49: 57-80.

Emerson, S., Grundmanis, V. and Graham, D., 1982. Carbonate chemistry in marine pore waters: MANOP sites C and S. Earth Planet. Sci. Lett., 61: 220-232.

Froelich, P.N., Klinkhammer, G.P., Bender, M.L., Luedtke, N.A., Heath, G.R., Cullen, D., Dauphin, P., Hammond, D., Hartman, B. and Maynard, V., 1979. Early oxidation of organic matter in pelagic sediments of the eastern equatorial Atlantic: suboxic diagenesis. Geochim. Cosmochim. Acta, 43: 1075-1090.

Ganssen, G.M. and Troelstra, S.R., 1987. Paleoenvironmental changes from stable isotopes in planktonic foraminifera from Eastern Mediterranean sapropels. In: J.E. van Hinte, M.B. Cita and C.H. van der Weijden (Editors), Extant and Ancient Anoxic Basin Conditions in the Eastern Mediterranean. Mar. Geol., 75: 221-230 (this volume).

Gieskes, J.M., 1973. Interstitial water studies, Leg 15. In: B.C. Heezen, I.D. MacGregor et al., Initial Reports of the Deep Sea Drilling Project, Vol.20. U.S. Govt. Printing Office, Washington, D.C., pp.813-829.

Gieskes, J.M., 1983. The chemistry of interstitial waters of deep sea sediments: interpretation of Deep Sea Drilling Data. In: J.P. Riley and R. Chester (Editors), Chemical Oceanography, 8. Academic Press, New York, N.Y., pp.221-269.

Gieskes, J.M., Kastner, M. and Warner, T.B.W., 1975. Evidence for extensive diagenesis, Madagascar Basin, Deep Sea Drilling Site 245. Geochim. Cosmochim. Acta, 39: 1385-1394.

Grasshoff, K., Ehrhardt, M. and Kremling, K., 1983. Methods of Seawater Analysis. Chemie Verlag, Weinheim, 2nd ed., $419 \mathrm{pp}$.

Hartman, M., Müller, P.J., Suess, E. and Van der Weijden, C.H., 1973. Oxidation of organic matter in recent marine sediments. "Meteor" Forschungsergeb., Reihe C, 12: $74-86$.

Hawkesworth, C.J. and Elderfield, H., 1978. The strontium isotopic composition of interstitial waters from Sites 245 and 336 of the Deep Sea Drilling Project. Earth Planet. Sci. Lett., 40: 423-432.

Hsü, K.J., 1972. Origin of saline giants: a critical review 
after the discovery of the Mediterranean evaporite. Earth-Sci. Rev., 8: 371-396.

Jongsma, D., 1987. The geometry and rates of microplate motions in the Eastern Mediterranean Sea - Quantitative constraints by using anoxic basins as piercing points. In: J.E. van Hinte, M.B. Cita and C.H. van der Weijden (Editors), Extant and Ancient Anoxic Basin Conditions in the Eastern Mediterranean. Mar. Geol., 75: 1-29 (this volume).

Jongsma, D., Fortuin, A.R., Huson, W., Troelstra, S.R., Klaver, G.T., Peters, J.M., Van Harten, D., De Lange, G.J. and Ten Haven, H.L., 1983. Discovery of an anoxic basin within the Strabo Trench, eastern Mediterranean. Nature, 305: 795-797.

Kidd, R.B., Cita, M.B. and Ryan, W.B.F., 1978. Stratigraphy of eastern Mediterranean sapropel sequences recovered during DSDP Leg 42A and their paleoenvironmental significance. In: K.J. Hsü, L. Montadert et al., Initial Reports of the Deep Sea Drilling Project, Vol. 42A. U.S. Govt. Printing Office, Washington, D.C., pp.421-443.

Kuehn, R. and Hsü, K.J., 1978. Chemistry of halite and potash salt cores, DSDP Sites 374 and 376, Leg 42A, Mediterranean sea. In: K.J. Hsü, L. Montadert et al., Initial Reports of the Deep Sea Drilling Project, Vol. 42A. U.S. Govt. Printing Office, Washington, D.C., pp.613-619.

Leité, O. and Mascle, J., 1982. Geological structures on the South Cretan continental margin and Hellenic Trench (eastern Mediterranean). Mar. Geol., 49: 199-223.

Le Pichon, X., Angelier, J., Aubouin, J., Lyberis, N., Monti, S., Renard, V., Got, H., Hsü, K., Mart, Y., Mascle, J., Matthews, D., Mitropoulos, D., Isoflias, P. and Chronis, G., 1979. From subduction to transformation: a seabeam survey of the Hellenic trench system. Earth Planet. Sci. Lett., 44: 441-450.

Li, Y.H. and Gregory, S., 1974. Diffusion of ions in sea water and in deep-sea sediments. Geochim. Cosmochim. Acta, 38: 703-714.

Mannheim, F.T., 1976. Interstitial waters of marine sediments. In: J.P. Riley and R. Chester (Editors), Chemical Oceanography, 6. Academic Press, New York, N.Y., pp.115-186.

McCoy, F.W., 1980. Photographic analysis of coring. Mar. Geol., 38: 263-282.

McCoy, F.W. and Stanley, D.J., 1984. Formation of sapropels in the Tyro basin. Nature, 309: p.727.

McDuff, R.E. and Ellis, R.A., 1979. Determining diffusion coefficients in marine sediments: a laboratory study of the validity of resistivity techniques. Am. J. Sci., 279: 666-675.

McDuff, R.E. and Gieskes, J.M., 1976. Calcium and magnesium profiles in DSDP interstitial waters: diffusion or reaction? Earth Planet. Sci. Lett., 33: 1-10.

McDuff, R.E., Gieskes, J.M. and Lawrence, J.R., 1978. Interstitial water studies, Leg 42A. In: K.J. Hsü, L. Montadert et al., Initial Reports of the Deep Sea Drilling Project, Vol. 42. U.S. Govt. Printing Office, Washington, D.C., pp.561-568.
Michard, G., Church, T.M. and Bernat, M., 1974. The porewater chemistry of recent sediments in the western Mediterranean basin. J. Geophys. Res., 79: 817-824.

Milliman, J.D. and Müller, J., 1973. Precipitation and lithification of magnesian calcite in the deep sea sediments of the eastern Mediterranean sea. Sedimentology, 20: 29-45.

Müller, P.J. and Suess, E., 1979. Productivity, sedimentation rate, and sedimentary organic matter in the oceans - I. Organic carbon preservation. Deep-Sea Res., 26A: 1347-1362.

Murray, J.W., Emerson, S. and Jahnke, R., 1980. Carbonate saturation and the effect of pressure on the alkalinity of interstitial waters from the Guatamala basin. Geochim. Cosmochim. Acta, 44: 963-972.

Peters, J.M. and Huson, W.J., 1985. The Pliny and Strabo trenches (eastern Mediterranean): integration of seismic reflection data and Seabeam bathymetric maps. Mar. Geol., 64: 1-17.

Presley, B.J., Petrowski, C. and Kaplan, I.R., 1972. Interstitial water chemistry: Deep Sea Drilling Project Leg 13. In: W.B.F. Ryan, K.J. Hsü et al., Initial Reports of the Deep Sea Drilling Project, Vol. 13. U.S. Govt. Printing Office, Washington, D.C., pp.809-811.

Redfield, A.C., 1958. The biological control of chemical factors in the environment. Am. J. Sci., 46: 206-226.

Reeburgh, W.S., 1967. An improved interstitial water sampler. Limnol. Oceanogr., 12: 163-165.

Rosenfeld, J.K., 1981. Nitrogen diagenesis in Long Island sound sediments. Am. J. Sci., 281: 436-462.

Russell, K.L., 1970. Geochemistry and harmyrolysis of clay minerals, Rio Ameco/Mexico. Geochim. Cosmochim. Acta, 34: 893-907.

Sayles, F.L., 1979. The composition and diagenesis in deeply buried marine sediments - I. Fluxes across the seawater-sediment interface in the Atlantic Ocean. Geochim. Cosmochim. Acta, 43: 527-545.

Sayles, F.L., Waterman, L.S. and Mannheim, F.T., 1972. Interstitial water studies on small core samples from the Mediterranean sea. In: W.B.F. Ryan, K.J. Hsü et al., Initial Reports of the Deep Sea Drilling Project, Vol. 13. U.S. Govt. Printing Office, Washington, D.C., pp.801-808.

Scientific staff of cruise Bannock 1984-12, 1985. Gypsum precipitation from cold brines in an anoxic basin in the eastern Mediterranean. Nature, 314: 152-154.

Sholkovitz, E., 1973. Interstitial water chemistry of Santa Barbara basin sediments. Geochim. Cosmochim. Acta, 37: 2043-2073.

Sjöberg, E.L, Georgala, D. and Rickard, D.T., 1984. Origin of interstitial water compositions in postglacial black clays (northeastern Sweden). Chem. Geol., 42: 147-158.

Strickland, J.D.H. and Parsons, T.R., 1968. A practical handbook of seawater analysis. Bull. Fish. Res. Board Can., 167: 1-311.

Sutherland, H.E., Calvert, S.E. and Morris, R.J., 1984. Geochemical studies of the recent sapropel and associated sediment from the Hellenic outer ridge, eastern 
Mediterranean Sea. I: Mineralogy and chemical composition. Mar. Geol., 56: 79-92.

Ten Haven, H.L., De Lange, G.J. and Klaver, G.Th., 1985. The chemical composition and origin of the Tyro brine, eastern Mediterranean. A tentative model. Mar. Geol., 64: 337-342.

Ten Haven, H.L., Baas, M., De Leeuw, J.W. and Schenck, P.A., 1987a. Late Quaternary Mediterranean sapropels, I - On the origin of the organic matter in sapropel $S_{7}$. In: J.E. van Hinte, M.B. Cita and C.H. van der Weijden (Editors), Extant and Ancient Anoxic Basin Conditions in the Eastern Mediterranean. Mar. Geol., 75: 137-156 (this volume).
Ten Haven, H.L., Baas, M., De Leeuw, J.W., Schenck, P.A. and Brinkhuis, H., 1987b. Late Quaternary Mediterranean sapropels, II - Lateral variation in organic geochemistry and palynology of $S_{1}$ sapropels. Chem. Geol., 64 (in press).

Troelstra, S.R., 1987. Late Quaternary sedimentation in the Tyro and Kretheus basins, southeast of Crete. In: J.E. van Hinte, M.B. Cita and C.H. van der Weijden (Editors), Extant and Ancient Anoxic Basin Conditions in the Eastern Mediterranean. Mar. Geol., 75: 77-91 (this volume).

Vogel, A.I., 1961. A Text-book of Quantitative Inorganic Analysis. Longmans, London, $1216 \mathrm{pp}$. 